exceeds the diameter of the float; the cylinders were made up in sections of fifty inches in length, the lowest of which is closed below with an iron plate, and the whole, when bolted together, forms a water-tight well, into which water can only enter through the piping for effecting the connection with the sea. The piping is of an internal diameter of two inches, which has been computed to be sufficient to permit of the transmission of the tidal wave to the well without sensible retardation. Iron piping is laid from the well to the line of low water; it is brought vertically up from the bottom of the well nearly to the surface of the ground, and is then carried down to the sea, where flexible gutta-percha piping is attached, and carried into the deep water. The outer piping terminates in a "rose," which is suspended a few feet above the bed of the sea by a buoy, in order to prevent the entrance of silt as much as possible, and it can be readily detached from the iron piping whenever it has to be cleaned.

After many difficulties, and even dangers to life, Capt, Baird's party managed to get the gauges erected and set to work, and what with the tidal observations, observations of the barometric pressure, the velocity and direction of the wind, and the amount of rainfall-for each station has been provided with means for making such observationsvery valuable results may be expected.

Lieut. Gibbs's notes on the portion of the Dang Forests, in the Guzerat district, visited by him in 1874 , are of great interest, and we regret that space forbids us referring to them in detail. His observations on the inhabitants of this region are of special value; he also seems to have paid considerable attention to the fama, fora, and geology of the district.

Capt. Heaviside's lively natrative of the pendulum work in India, of his joumey home, and of the operations at Kew, will also be read with interest.

Two narratives of somewhat musual interest are given in the Appendix. One of these, by Lieut.-Col. Montgomerie, gives an account of a journey to the Namcho or Tengri Nur Lake, in Great Thibet, about ninety miles north of the Brahmaputra, by a native explorer, during I871-72. The explorer was a semi-Thibetan, a young man who had been thoroughly trained for the work, and who was accompanied by four assistants. The party set out from Kumaon in November, and crossed the Brahmaputra at Shigatze, and anid considerable hardships made their way northwards, reaching the lake about the end of Jantiary, when they found it cormpletely frozen over, although the water is so salt as to be unfit for drinking. The party intended to travel all round the lake, which is I 5,200 feet above the sea, fifty miles long and from sixteen fo twenty. five miles broad, and intended to proceed further to the northward and rake complete surveys, but were robbed of nearly all they had, and were thus compelled to beat a rapid retreat, which they did by way of Lhásá.

During the great part of his joumey to the Namcho Lake the explorer found the streams all hard frozen, and he was consequently much struck by the number of hot springs that he met with, and more especially by the great heat of the water coming from them, his thermometer showing it to vary from $130^{\circ}$ to $183^{\circ}$ Fahrenheit, being generally over $150^{\circ}$, and often within a few degrees of the boiling point, being in one case $183^{\circ}$ when the boiling point was $183_{4}^{3 \circ}$. The water generally had a sulphurous smell, and in many cases was ejected with great noise and violence; in one place the force was sufficient to throw the water up from forty to sixty feet. These springs in some respects seem to resemble the geysers of Iceland.

To the south the lake is bounded by a splendid xange of snowy peaks, flanked with large glaciers, culminating in the magnificent peak "Jang Ninjinthanglá," which is probably more than 25,000 feet above the sea. The range was traced for nearly I50 miles, running in a northeasterly direction. To the north of the lake the moun- tains were not, comparatively speaking, high, nor were there any high peaks visible further north as far as the explorer could see from a commanding point which he climbed up to. He only saw a succession of rounded hills with moderately flat ground in between them. Immediately north he saw a lake of about six miles in length, which he was told was called Bul Cho, from the borax (bul) which is produced there in large quantities, sup. plying both Lhásá and Shigatze with most of the borax that they require.

The Tengri Nút or "Namcho" Lake is considered to be a sacred place, and although at such a very great distance from habitations and so high above the sea, it boasts of several permanent monasteries and is visited by large numbers of pilgrims. There are several islands in the lake, two of them large enough for monasteries: at the time the explorer was there the Lámas on the islands kept up their communication with the shore by means of the ice, but he did not hear as to what was done in summer. Fish are said to be abundant, and modern lake shells were found on the shore as well as fossil shells, which were very r.umerous and of all sizes.

The narrative contains many other valuable observations made on the people and the country through which he travelled; there is a good map of the route.

The other namative is quite equal in interest to that just referred to. It consists of extracts from a native explore's narrative of his journey from pitoragarh in Kumaon viât Jumla to Tadum, and then down through Nepaul, along the Gandak River, to British territory. The explorer, who had to exercise much determination and ingenuity, took minute notes by the way of all he saw, and has added much to our knowledge of the geography, the people, and the products of a region comparatively unknown. He had to cross many rivers by the way, which was generally done by means of ropes suspended between the banks. The explorer wished to proceed much further than Tadum, which is a little beyond the Brahmaputra, in Great Thibet, but was prevented by the head man of the village. He started on July I, 1873 , and reached British territory again about the end of Norember, after having travelled nearly 500 miles. We have space to notice only one interesting phenomenon which he observed. At Muktináth, near Kágbeni, about Ir,280 feet above the sea, in N. lat. $29^{\circ}$ and E. long. $83^{\circ} 45^{\prime}$, about 600 feet south of the temple, is a small mound with a little still water at its base, having a sulphurous smell. From a crevice in this mound, at the water's edge, rises a flame about a span above the surface. The people of the place told the explorer that the water sometimes increases in quantity sufficiently to flow into the crevice; the flames then disappear for a while, and there is a gurgling noise, a report, and the flames burst up and show again. This spot is called Chume Giarsa by the Bhots.

Our readers will see, from the cursory glance we have been able to take at this Report, that it contains much valuable matter apart from the immediate work of the Survey, the members of which are doing good service to India and to science.

\section{THE BIOLOGICAL DEPARTMENT OF THE BRITISH MUSEUM}

$7 \mathrm{HE}$ newlywissued Report of the condition and develop. ment of the British Museum has, so far as biologists are concerned, a special interest. Its results may be considered as an index of the public feeling on the importance of the study of Natural History, Looked at in this light, we think that specialists in all the departments may feel hopeful. The acquisisions to the Zoological Department have been numerous (30,699 in all), over 6,000 being Vertebrata, "the majority being either entir 
animals preserved in spirits, or skeletons." The spirit collection till recently has been much neglected, and all who have wished to prosecute their investigations into the more intricate details of zoology and comparative anatomy -into points of myology, nerve distribution, \&c., quite as important as, but much less easily arrived at than, osteological characters-may justifiably look forward to the time when the national collection will contain, preserved in their entirety, examples of all reasonably-sized species.

"In the acquisition by purchase of skeletons, particular care has been taken [we are told] that they should be those of animals captured in a wild state, the skeletons of inammals (and birds) which have been brought up or have lived for some time in menageries, showing rarely, if ever, a perfect development of the osseous system. Scarcely less caution is required in admitting specimens of this kind into the collection for the sake of their skins." There is a great deal of truth in these remarks, but there are many new species of animals, such as the new Mouming Kangaroo, brought over by M. d'Albertis, and the Hairyeared Rhinoceros (Rtinoceros lasiotis), discovered by Mr. Sclater, and now enjoying perfect health in the Zoological Society's Gardens, which are only known from these individuals.* It would be a loss to the collection if these were not obtained when opportunity afforded, and we are glad to know that the small kangaroo referred to has died and has been secured by $\mathrm{Dr}$. Günther.

We are informed that over three thousand students who have visited the department during the past year, with the object of consulting the various portions of the collections, "have been assisted and attended to." All, we are convinced, will agree in expressing their best thanks to Dr. Albert Giinther, who, as the worthy successor of the late Dr. J. E. Gray, has done all in his power to place every facility in the way of those who are desirous of studying Natural History.

\section{NOTES}

M. LEVERRIRR was expected in England during the present morth; but as the revision of his planetary theories, and especially of the Theory of Saturn, in which he has been ccculpied for some time, is not yet completed, his visit to this country will be celayert.

Tys Emperor of Brazil has sent to Prof. Virchow, accompanied by an autograph letter in French, an interesting collection of skulls and skeletons, amongst which are some found in ancient caverns of Brazil. The collection has been made at the Emperor's request by the director of the Museum at Rio, Señor Ladislas Neto. The Imperor regrets that he did not have the pleasure of making Prof. Virchow's acquaintance at Berlin when he visited that city, as the Professor's investigations "are highly esteemed even by those to whom, like myself, it is not given to be more than friends to science."

THE Geographical Society of Rome gave a banquet, on May II, to the celebrated African traveller Di. Nachtigal ; many of the members and several notabilities of the city of Rome were present in honour of the guest. The Vice-president of the Society, Senator Amari, proposed the health of the guest, who had just returned from a journey through Fezzan, Bornu, Wadai, and Darfur. Dr. Nachtigal, in reply, wished success to the scien. tific expedition to Central Africa planned by the Society; he considered that this expedition would be an honour to the whole Italian kingdom.

Tixe transfer of the India Museum to the Eastern Galleries of the International Exhibition Buildings, South Kensington, having been completed, the collection was thrown open to the * A second specimen of the latter species has been just received by
Mr. C. Jamrach.
Institute of Civil Engineers, who had a brilliant conversazione in the galleries on Tuesday evening; there were about 2,500 present. Considerable advance has been made in the arrangement of the valuable collections belonging to the Museum, though it must necessarily take some time before everything can find its proper place. There are two galleries, the upper and the lower. In the former, the Manufactures and Arts of India are represented; in the latter, which are not yet finished, the Natural History of Hindostan, the mineral, vegetable, and animal products, are represented. No doubt the India Museum, as it will ultimately be arranged, will become a favourite and instructive resort of the public, and we hope it is only the first step towards the realisation of Dr. Forbes Watson's great scheme of an Indian Institute.

Mr. H. H. SCLATER, the naturalist to the Rodrigues section of the Jate Transit of Venus Expecition, and the Rev. A. E. Eaton, who held the same position at Kerguelen's Land, are both working out the materials which they collected during their stay in the islands which they visited. The former zoologist has obtained a great number of remains of the extinct Solitaire, one skeleton and several skulls being perfect; besides the remains of several other species of birds. Mr. Eaton's specimens include the skeleton of one Cetacean, two Seals, and several species of Petrels.

DR. LXon Playgair has withdrawn his bill for restricting experiments on animals, on account of the appointment of a Royal Commission on the subject, the names of the members of which have not yet been published.

Prof. LEIDy, the distinguished American biologist, is now in this country.

THE volcanic phenomena in Iceland, of which we have already given some details (vol, xi. p. 514.) seem still to be as active as ever, and indeed to be gaining in intensity. Outbreaks have occurred since the begiming of the year to the middle of April, when the latest news left. In March the Dyngjufjöll was incessantly vomiting fire, the eruption was steadily spreading over the wilderness, and the whole region of the My-vatn Mountains was one blazing fi:e. So large a district of the surrounding country has been covered with ashes that the farmers have been obliged to re. move in order to find pasture for their stock. Early in A pril a new eruption had broken out in a south-easterly direction from Barfell, more than half-way to the east, between it and the Jokulsa. A party went ont from Laxárdal to explore, and on approaching the place of cruption they found the fixe rising up from three lava craters, in a line from south to rorth, which it had piled up around itself on a perfectly level piece of ground. At a distance of fifty to eighty fathoms to the west from the craters a large fissure had formed itself as the fire broke out, and the land had sunk in to the cepth of about three fathoms. Into the hollow this formed the lava had poured at first, but now it flowed in a south-westerly direction from the two southern craters. The northernmost crater had the appearance of being oblong, about 300 fathoms in length, and from this crater the molten red-hot lava was thrown about 200 or 300 feet into the air in one compact column. The top of this column then assumed a palmated appearance, and the lava fell down in small particles, like drops from a jet of water, which, as they became separated from the column, grew gradually darker, and split into many pieces, bursting into lesser and lesser fragments as they cooled. No flames were observed, but the glare proceeds from these columns and the seething lava in the craters. At times the explorers could count twenty to thirty of these columns. No real smoke accompanied the eruption, but a bluish steam, which expanded and whitened in colour as it rose to a greater distance from the crater, and such seemed to be the power of this blue jet of steam that it rose straight into the air for many hundreds of fathoms in despite of a heavy wind blowing. 